\title{
EVALUATION OF SPROUTING BROCCOLI (Brassicae oleraceae var. italica) GENOTYPES FOR GROWTH, YIELD AND QUALITY
}

\section{THAPA U. AND RAI R.}

Department of Vegetable Crops Faculty of Horticulture, Bidhan Chandra Krishi Viswavidyalaya, Mohanpur, Nadia -741252, WB, India. *Corresponding Author: Email- drumesh.thapa@gmail.com

\author{
Received: October 11, 2012; Accepted: October 22, 2012
}

\begin{abstract}
Vegetables play a very important role in our daily diet. As an unconventional vegetable "Broccoli" is yet to gain the desired popularity in our country. It is very rich source of various anti-cancer agents as well as Vitamin $\mathrm{C}$ and dietary fibre. However, considerable attention is being given on the production technology of Broccoli which are rich in nutrient content and greater yield potential. But yet, No systematic work has been done on evaluation and commercialization of high value nutrient rich this cole crops. Therefore, the present study were carried out at Horticultural Research Station, Mondouri, Bidhan Chandra Krishi Viswavidyalaya, Mohanpur, Nadia in West Bengal during [2010-2012] rabi season with objectives to standardize the production technology of sprouting broccoli. Cultivation of these value added vegetables can boost the income of farmers due to very high market price and export demand. The investigations were followed in Randomized Block Design with three replications. Twelve varieties of Broccoli [Viz. Fiesta, Princess, Sultan , Nokguk , Early You, KE-180 , Priya , Puspa , Grandsino , Rapido , Prema and Packman] were evaluated. Observations recorded under the physical and chemical parameters of different varieties of genotype. In general, the performances of this crop with different hybrid varieties proved that there is ample scope to grow broccoli vegetable due to prevailing suitable agro - climatic condition as well as the gaining importance as potential vegetable for export. Among all the varieties of Broccoli Nokguk was found superior, which gave higher yield [145.47g/ha] in combination with best head formation. Whereas, in chemical analysis KE-180 variety was found outstanding position in chlorophyll $b$, reducing sugar, total sugar and carotene content among all the other genotypes taken under observation. So, proper management practices are highly required for the cultivation of this crop.
\end{abstract}

Keywords- Evaluation, broccoli, varieties, quality and yield

Citation: Thapa U. and Rai R. (2012) Evaluation of Sprouting Broccoli (Brassicae oleraceae var. italica) genotypes for growth, yield and quality. International Journal of Agriculture Sciences, ISSN: 0975-3710 \& E-ISSN: 0975-9107, Volume 4, Issue 7, pp-284-286.

Copyright: Copyright@2012 Thapa U. and Rai R. This is an open-access article distributed under the terms of the Creative Commons Attribution License, which permits unrestricted use, distribution and reproduction in any medium, provided the original author and source are credited.

\section{Introduction}

India is endowed with a wide range of tropical, sub-tropical and temperate vegetable crops. But still there are some vegetables which are lesser known or rare to most of our growers and consumers. Our farmers can earn a lot of profit by growing this rare or unusual high value Cole vegetables nearby big cities (peri-urban areas) and towns as they attract very high prices in cosmopolitan markets, star hotels and places of tourists' interest. They can also be exported to foreign especially European countries where their cultivation is not possible throughout the year in open field conditions. But due to lack of information about their cultural practices for our conditions the production or availability of these vegetables is still meager. Chinese cabbage, Sprouting broccoli , Red cabbage and Brussels sprouts, etc. have opened up new opportunities for vegetable growers of our country for diversification and off-season production for high market in metropolis. But due to lack of preference in food among Indians some of the introduced vegetables could not get popularity though they are rich in protein, carbohydrates, minerals, vitamins and fibers etc. However, with the growing tourist industry and nutritional awareness among people, these vegetables are gaining popular. Among the Cole crops broccoli is more nutritious than other Cole crops, such as cabbage, cauliflower and kohlrabi. It is fairly rich in carotene and ascorbic acid and contains appreciate quantities of thiamin, riboflavin, niacin and iron. Realizing the tremendous potential of sprouting broccoli in domestic and foreign market, the cauliflowers growers of terai zone of West Bengal (India) are gradually adopting the broccoli cultivation [3]. To popularize this high value Cole crops and its variety among the marginal and small farmers, proper demonstration should be adopted through personal contact approach, monitoring, motivation and awareness creation about benefits. Efforts are being made on long way in making farmers and consumers of West Bengal, India in adopting new exotic vegetables and varieties, which created an impact on ground level and helped the state in a big way in addressing/lessening the problems of hunger, under nutrition and 
malnutrition not only in West Bengal but elsewhere in the country as well. But no systematic work has been done on evaluation of these vegetables in our region. However, State is facilitated with good and congenial agro-climatic condition for cultivation of these crops. Therefore, present studies were aimed at promotion of high value Cole vegetables by identifying new promising varieties with high productivity under wide range of environmental conditions, better horticultural characteristics and market opportunities.

\section{Materials and Methods}

The present studies were carried out at Horticultural Research Station, Mondouri, Bidhan Chandra Krishi Viswavidyalaya, Mohanpur, Nadia in West Bengal during rabi season [2010-2012] with the principle objective to standardize the production technology of sprouting broccoli. The investigation details are as follows:

Broccoli [Brassica oleraceae var. italica] were planted in the rabi season. The design of experimental site was Randomized Block Design replicated thrice utilizing twelve genotypes showing diverse features. Genotypes taken under observations were Fiesta, Princess, Sultan, Nokguk, Early you, Priya, Puspa, Grandsino, Rapido, Prema, and Packman. The transplanting of seedlings were accomplished on first week of November with the spacing of $[60 \mathrm{~cm} x$ $45 \mathrm{~cm}$ ]. Applied fertilizer doses are in NPK ratio of [100:80:100] kg per hectare. Regular cultural practices, crop protection measures were adopted as per the requirements of crop. Observations were taken under physical, yield and quality attributing parameters. Mean value of randomized data were analysed by following standard statistical technique [2].

\section{Results and Discussion}

The twelve different varieties of Broccoli were varied significantly. The height of the plants varied from [30.78 to $41.69 \mathrm{~cm}$ ]. From the data it revealed that the variety, Nokguk recorded significantly maximum plant height $[41.69 \mathrm{~cm}$ ] while Early You variety recorded the minimum $[30.78 \mathrm{~cm}]$. The lowest plant height observed in some other varieties might be due to its inherent genotypic characteristics or for the variations in agro-climatic condition. The number of leaves per plant is an important character that might influence the yield. The cultivars included in the study produced an average variation of [11. 33 to 20.20] leaves per plant. The maximum number of leaves per plant was recorded as [20.20] in variety Fiesta, followed by Nokguk [19.00], Grand Sino [18.077], and Priya [15.30]. The lowest number of leaves was noticed in the variety Puspa [11.33] Sultan [11.93], Early You [12.06] and Princess [13.07]. Lower number of leaves in some cultivars was probably due to slow rate in leaf initiation which would be an inherent character of the cultivars. This is in agreement with previous investigation in which some of the cultivars were included [1-3, 5]. In determining the photosynthetic efficiency of the leaves, the surface area of the leaves is an important factor. In this investigation, plant spread in each cultivar were recorded and found significant differences. The range of plant spread was [ 4515.87 to $\left.6641.81 \mathrm{~cm}^{2}\right]$. It has been found from the experiment results, the maximum plant spread $\left[6641.81 \mathrm{~cm}^{2}\right]$ was obtained with variety Princes. The minimum plant spread of [ $\left.4515.87 \mathrm{~cm}^{2}\right]$, with variety Puspa was recorded.

It has been found from the experimental results that the highest stem diameter was measured in variety Prema $[3.77 \mathrm{~cm}]$ followed by Grandsino $[3.70 \mathrm{~cm}]$. Similarly the higher site in diameter of stem was observed with variety Princes [3.67 cm], Nokguk [3.67 $\mathrm{cm}]$, and Early You [3.66 cm]. From the [Table-1] it is clear that among the above mentioned varieties there were significant differences among themselves. Rest of the other varieties different significantly from the above mentioned one. However, the lowest diameter of stem was obtained with variety Fiesta $[3.32 \mathrm{~cm}]$. This similarity and dissimilarity among the varieties in stem diameter may be attributed to the variability in their genetic configuration. In respect of the stem length, statistically parity was observed. Among the twelve varieties the minimum stem length $[20.42 \mathrm{~cm}]$ was observed in variety Early You. This showed that the cultivars represent a good range of genetic diversity in response of stem length.

Yield and yield attributing characters due to different varieties showed a significant differences effect. In respect of earliness of head initiation and days required to harvesting, the cultivars under study were found significant. The average number of days to head initiation varied from [59.00 to 70.00]. The cultivar Early You, Sultan, Puspa, Rapido, Prema and Packman found earlier and Grandsino found very late in respect of head initiation. The average period required days to harvesting varied from [72.00 to 85.67]. The highest head diameter was recorded in Nokguk [23.63cm] followed by Early You [21.70 cm].

Table 1- Varietal evaluation of different varieties of Broccoli Significant increase in head weight was observed in response to different varieties.

\begin{tabular}{|c|c|c|c|c|c|c|c|c|c|c|c|c|c|c|}
\hline Variety & $\begin{array}{l}\text { Days to Head } \\
\text { initiation } \\
\text { (Days) }\end{array}$ & $\begin{array}{l}\text { Days to } \\
\text { harvest } \\
\text { (Days) }\end{array}$ & $\begin{array}{l}\text { Plant } \\
\text { height } \\
\text { (cm) }\end{array}$ & $\begin{array}{l}\text { Plant } \\
\text { spread } \\
\left(\mathrm{cm}^{2}\right)\end{array}$ & $\begin{array}{l}\text { Number of } \\
\text { leaves }\end{array}$ & $\begin{array}{l}\text { Leaf area } \\
\qquad\left(\mathrm{cm}^{2}\right)\end{array}$ & $\begin{array}{l}\text { Head } \\
\text { diameter } \\
(\mathrm{cm})\end{array}$ & $\begin{array}{l}\text { Stem } \\
\text { diameter } \\
\text { (cm) }\end{array}$ & $\begin{array}{l}\text { Stem } \\
\text { length } \\
(\mathrm{cm})\end{array}$ & $\begin{array}{l}\text { Number of } \\
\text { sprout }\end{array}$ & $\begin{array}{l}\text { Sprout } \\
\text { weight } \\
\text { (gm.) }\end{array}$ & $\begin{array}{l}\text { Sprout } \\
\text { yield/plot } \\
\text { (kg) }\end{array}$ & $\begin{array}{l}\text { Head } \\
\text { weight } \\
\text { (gm.) }\end{array}$ & $\begin{array}{l}\text { Yield } \\
\text { (q/ha) }\end{array}$ \\
\hline Fiesta & 67.67 & 80.67 & 40.74 & 5009.58 & 20.2 & 4961.14 & 21.64 & 3.32 & 30.29 & 3.67 & 25.72 & 1.5 & 233.83 & 93.53 \\
\hline Sultan & 59 & 72 & 32.47 & 4987.08 & 11.93 & 812.32 & 19.99 & 3.39 & 21.31 & 3.92 & 64.68 & 4 & 259.56 & 103.83 \\
\hline Nokguk & 63.67 & 78.33 & 41.69 & 5543.19 & 19 & 464.39 & 23.63 & 3.67 & 28.92 & 1.35 & 57 & 1.24 & 375 & 145.47 \\
\hline Early you & 59 & 72 & 30.78 & 5775.74 & 12.06 & 887.18 & 21.7 & 3.66 & 20.42 & 5.16 & 35.79 & 2.94 & 333.67 & 128.11 \\
\hline Priya & 63.67 & 73 & 36.61 & 5913.78 & 15.3 & 1022.68 & 20.14 & 3.63 & 26.67 & 6.1 & 33.43 & 3.26 & 255.83 & 102.33 \\
\hline Puspa & 59 & 73 & 33.07 & 4515.87 & 11.33 & 896.48 & 20.17 & 3.49 & 21.67 & 4.77 & 31 & 2.36 & 289 & 115.6 \\
\hline Grandsino & 70 & 78.33 & 34.7 & 5708.6 & 18.07 & 720.55 & 21.1 & 3.72 & 26.4 & 2.4 & 76.55 & 2.95 & 281.67 & 112.67 \\
\hline Rapido & 59 & 72 & 40 & 5731.59 & 15.2 & 945.95 & 20.65 & 3.55 & 28.53 & 3.81 & 30.25 & 1.84 & 253.33 & 114.83 \\
\hline Prema & 59 & 74.4 & 35.2 & 5367.55 & 13.3 & 1112.09 & 21.57 & 3.77 & 23.6 & 4.06 & 27.67 & 1.8 & 263.89 & 108 \\
\hline Packman & 59 & 77.33 & 36.2 & 4785.67 & 13.4 & 1108.49 & 19.37 & 3.65 & 24.3 & 4.69 & 40.93 & 3.05 & 279.6 & 111.6 \\
\hline $\operatorname{SEm}( \pm)$ & 3.0965 & 2.6328 & 1.403 & 520.038 & 1.0502 & 1045.85 & 0.9925 & 0.1782 & 1.8655 & 0.4477 & 4.493 & 0.345 & 34.081 & 13.004 \\
\hline CD at $5 \%$ & 6.3651 & 5.4118 & 2.884 & 1068.96 & 2.1587 & 2149.79 & 2.0402 & 0.3662 & 3.8846 & 0.9203 & 9.236 & 0.7104 & 70.055 & 26.731 \\
\hline
\end{tabular}


The maximum head weight of [375.00gm] was found with Nokguk, variety. The varieties which produced comparatively more head weight are namely Early You, Prema, Fiesta, Princes, Packman and Puspa. The highest head weight might be due to resulted from the highest head diameter of the respective varieties. The minimum head weight of [233.83.gm] was obtained with Grandsino variety. There was a significant and positive effect of different varieties on head yield [q/ha] Nokguk performed the highest results in head yield [149.74q/ha] and the other two varieties showed statistically similar results [120.86 q/ha, $119.72 \mathrm{q} / \mathrm{ha}$ ]. It indicates that next to Nokguk, there two varieties, Early You and Princes have ability to produced good head yield. The other remaining varieties has produced similar head yield. The tabulated data [Table-1.] showed clearly that the best quality of more number of sprout (spears) was recorded from the variety Priya followed by Early You. The lowest numbers of sprout were observed from Nokguk variety. The differ- ences in number of sprout among these varieties may be due to their own genetic characters. Results obtained in [Table-1] reflect significant differences in the sprout weight of the different varieties. The highest sprout weight was obtained from Grandsino followed by Nokguk.

Quality parameters were also analysed in [Table-2] such as total soluble solids, reducing sugar, non-reducing sugar, total sugar, ascorbic acid, chlorophyll 'a', chlorophyll 'b', total chlorophyll and carotene. Among all the varieties of Broccoli, variety KE-180 reported maximum chlorophyll 'b' [1.65 mg/lit], carotene [3.13ug/100g], total sugar $[3.22 \%]$ and reducing sugar [2.91\%]. Total chlorophyll was found maximum [1.46 mg/lit] in variety Priya. Variety Prema gave maximum TSS of [11.25*Brix] in compare to other varieties and variety Sultan have relatively high ascorbic acid of [98.5 $\mathrm{mg} / 100 \mathrm{gm}]$.

Table 2- Varietal evaluation on Quality attributes of broccoli

\begin{tabular}{|c|c|c|c|c|c|c|c|c|c|}
\hline Variety & $\begin{array}{l}\text { Chlorophyll } \\
\text { 'a'(mg/lit) }\end{array}$ & $\begin{array}{l}\text { Chlorophyll } \\
\text { 'b'(mg/lit) }\end{array}$ & $\begin{array}{l}\text { Total Chloro- } \\
\text { phyll (mg/lit) }\end{array}$ & T.S.S ( ${ }^{*}$ Brix) & $\begin{array}{l}\text { Carotene } \\
\text { (ug/100g) }\end{array}$ & $\begin{array}{l}\text { Ascorbic acid } \\
\text { (mg/100 gm.) }\end{array}$ & Total sugar (\%) & $\begin{array}{l}\text { Reducing } \\
\text { sugar (\%) }\end{array}$ & $\begin{array}{l}\text { Non-Reducing } \\
\text { sugar }(\%)\end{array}$ \\
\hline Fiesta & 0.0926 & 0.709 & 0.514 & 11.08 & 2.02 & 89.7 & 3.17 & 2.75 & 0.42 \\
\hline Princies & 0.747 & 1.333 & 2.023 & 8.58 & 2 & 82 & 2.23 & 1.98 & 0.25 \\
\hline Sultan & 0.334 & 0.798 & 0.997 & 8.42 & 0.24 & 98.5 & 2.34 & 2.01 & 0.33 \\
\hline Nokguk & 0.158 & 0.488 & 0.526 & 9.17 & 2.23 & 89.1 & 2.12 & 1.86 & 0.25 \\
\hline Early you & 0.453 & 1.285 & 1.452 & 10 & 2.19 & 88.7 & 2.45 & 2.08 & 0.36 \\
\hline KE-180 & 0.223 & 1.65 & 1.218 & 10.233 & 3.12 & 95.8 & 3.22 & 2.91 & 0.32 \\
\hline Priya & 0.71 & 0.349 & 1.468 & 11.17 & 2.38 & 87 & 1.93 & 1.64 & 0.29 \\
\hline Puspa & 0.351 & 0.808 & 1.084 & 8.42 & 1.71 & 94.5 & 2.18 & 1.91 & 0.26 \\
\hline Grandsino & 0.287 & 0.312 & 0.676 & 10.37 & 1.99 & 84.8 & 2.31 & 2.02 & 0.29 \\
\hline Rapido & 0.155 & 0.697 & 0.623 & 8.33 & 1.07 & 91.5 & 2.47 & 2.12 & 0.35 \\
\hline Prema & 0.09 & 0.246 & 0.285 & 11.25 & 1.96 & 92 & 1.83 & 1.52 & 0.32 \\
\hline Packman & 0.244 & 1.054 & 0.959 & 10.33 & 2.39 & 88.1 & 3.18 & 2.82 & 0.36 \\
\hline $\operatorname{SEm}( \pm)$ & 0.173 & 0.2655 & 0.3564 & 0.2906 & 0.2882 & 1.894 & 0.0148 & 0.0223 & 0.0302 \\
\hline CD at $5 \%$ & 0.3556 & 0.5458 & 0.7326 & 0.5973 & 0.5925 & 2.588 & 0.0304 & 0.0457 & 0.0621 \\
\hline
\end{tabular}

The present experiment revealed that the yield and yield attributing characters significantly differed within the different varieties. On the basis of performance of varieties related to head yield and concerning yield attributing characters, Nokguk performed the highest head yield and other two varieties Early You, and Princes are also considered suitable for positive response for boosting higher yield.

\section{References}

[1] McCall D. Sorensen L. and Jensen B.D. (1996) S.P. Rapport Statens Planteavlsforsog, 8, 32.

[2] Panse V.G. and Sukhatme P.V. (1985) Statistical Methods for Agricultural Workers, 4th ed., ICAR, New Delhi, 347.

[3] Rooster L.de., Callens D., de-Rooster L. (1998) Proeftuinnieuws, 8(22), 31-32.

[4] Saha P., Chatterjee R. and Mukhopadhyay D. (2006) Crop Research Hisar, 32(3), 396-400.

[5] Vanparys L. (1998) Proeftuinnieuws, 8(14), 29-31. 